\title{
СЕРЦЕВО-СУДИННІ ФАКТОРИ РИЗИКУ У ХВОРИХ НА ПРОГРАМНОМУ ГЕМОДІАЛІЗІ 3 УРАХУВАННЯМ ЦУКРОВОГО ДІАБЕТУ 2-ГО ТИПУ
}

\section{С.Т. Рустамян, І.П. Катеренчук}

Полтавський державний медичний університет, м. Полтава

Резюме. У статті наведено дані щодо серцево-судинного ризику у хворих на програмному гемодіалізі з урахуванням цукрового діабету 2-го типу. Доведено, що пацієнти з хронічною хворобою нирок мають високий та дуже високий серцево-судинний ризик. Наявність цукрового діабету збільшує серцево-судинний ризик. Важливою складовою для зменшення кардіоваскулярного ризику є контроль глікемії, ліпідного профілю, рівня кальцію та фосфрору сироватки крові.

Ключові слова: гемодіаліз, цукровий діабет, фрактори ризику.

\section{Cardiovascular risk factors in patients receiving treatment by programmed hemodyalisis taking into account the presence of type ii diabetes mellitus}

\author{
S.T. Rustamian, I.P. Katerenchuk \\ Poltava state medical university, Poltava
}

Abstract. The article presents data about the cardiovascular risk factors in patients on treatment with programmed hemodyalisis taking into the account the presence of type II diabetes mellitus. It was estimated that patients suffering on chronic kidney disease have high and extremely high levels of cardiovascular risk. The presence of type II diabetes mellitus significantly increases the level of cardiovascular risk. The important component of complex cardiovascular risk reduction measures is a strong control under the blood glucose, calcium and phosphorus concentrations in the serum.

Keywords: hemodyalisis, diabetes mellitus, risk factors.

УДК: 616.379-008.64:612.17 DOI: $10.31793 / 2709-7404.2021 .2-2.61$

(C) С.Т. Рустамян, І.П. Катеренчук Надійшла до редакції 03.06.2021

Адреса для листування (Correspondence): Полтавський державний медичний університет, вул. Шевченка, 23, м. Полтава, 36024, Україна.E-mail: zdovado@ukr.net 


\section{Вступ}

Хронічна хвороба нирок (ХХH) стає поширеним захворюванням у загальній популяції та пов'язана із підвищеним ризиком смертності. Активне впровадження новітніх технологій для лікування хворих із термінальною нирковою недостатністю й раціональна фармакотерапія коморбідних станів та ускладнень істотно змінили якість і тривалість життя цієї категорії пацієнтів, але смертність порівняно із загальною популяцією залишається на високому рівні [1]. Така висока смертність мотивує не тільки зарубіжних, а й українських науковців до пошуку потенційних факторів, які найбільш загрозливо впливають на ускладнення основного захворювання діалізних пацієнтів [2, 3]. Доведено, що основною причиною смерті та незалежним фрактором ризику в цій популяції $€$ серцево-судинні захворювання. Основними «традиційними» фракторами ризику серцево-судинних захворювань (СС3) є артеріальна гіпертензія, цукровий діабет (ЦД), ожиріння, дисліпідемія (підвищений загальний рівень холестерину та ліпопротеїдів низької щільності (ЛПНЩ), знижений рівень ліпопротеїдів високої щільності (ЛПВЩ) та гіпертригліцеридемія) [4]. Але потрібно виділити також «нетрадиційні» ниркові фактори, які можуть впливати на ризик розвитку та патогенез ССЗ: анемія, порушення фосфорно-кальцієвого обміну, гіпергідратація, системне запалення, гіперкоагуляція. Серцево-судинна патологія та ранній розвиток атеросклерозу є основними причинами смерті хворих із термінальною стадією ХНН, а метаболічні порушення значною мірою впливають на прогноз та якість життя цієї категорії хворих. Ускладнення, такі як ішемічна хвороба серця (стенокардія, кардіосклероз, інфаркт міокарда, серцева недостатність), метаболічна кардіоміопатія, клапанні вади (стеноз і недостатність), зазвичай можна віднести до розладів структури та функції серцевих м'язів, метаболічних і гемодинамічних розладів. За даними численних досліджень, навіть незначне зниження функції нирок асоційовано зі збільшенням ризику СС3 та смертності незалежно від інших факторів ризику. Супутній ЦДє коморбідним захворюванням, що ускладнює перебіг серцево-судинних захворювань у хворих із термінальною стадією XXH, що доведено багатьма дослідженнями $[4,5]$. При ЦД нирки вражаються приблизно у 20-40\% людей [6]. Взаємозв'язок ЦД та ССЗ є відомим фактом та підтверджений багатьма науковими дослідженнями. При цьому
ЦД визнаний як незалежний фактор кардіоваскулярного ризику. ЦД та XXН синергічно збільшують ризик розвитку кардіоваскулярних захворювань [7]. Дослідження кардіоваскулярного ризику у хворих, що перебувають на нирково-замісній терапії (НЗТ) з урахуванням наявності ЦД, дасть змогу правильно підібрати грамотне лікування для цієї категорії хворих, що в подальшому може покращити як фрізичний стан, так і якість життя.

Мета. Вивчити особливості серцево-судинного ризику у хворих на програмному гемодіалізі з урахуванням наявності цукрового діабету 2-го типу.

\section{Матеріали та методи}

Після отримання письмової згоди на проведення інтерв'ювання відповідно до принципів Гельсінської декларації прав людини, Конвенції Ради Європи про права людини і біомедицину, відповідних законів України та міжнародних актів у рандомізований спосіб із попередньою стратифікацією, наявністю XXН (наказ Міністерства охорони здоров'я України № 89 від 11.02.2016 «Про надання медичної допомоги хворим з хронічною хворобою нирок V стадії із застосуванням гемодіалізу або перитонеального діалізу»), ЦД 2-го типу (наказ Міністерства охорони здоров'я України № 1118 від 21.12.2012) та його відсутності в дослідження залучено 93 хворих, які лікувалися на базі центру нефрології та діалізу КП «Полтавська обласна клінічна лікарня ім. М.В. Скліфосовського ПОР». Проведено ретроспективний аналіз 44 медичних карт хворих, що перебували на програмному гемодіалізі. Усім гемодіалізним хворим проводився стандартний бікарбонатний діаліз три рази на тиждень по 4 години. Індекс eKt/V у всіх діалізних хворих становив вище від 1,2. При аналізі медичних карт було виділено 2 підгрупи: перша - 20 медичних карт із діагнозом «діабетична несропатія» (ДГ1), інші 24 — пацієнти без ЦД (ДГ2). Середня тривалість лікування нирково-замісною терапією становила 6,2ะ6,7 року. Середній вік гемодіалізних хворих становив 50,1 11,8 року, причому в ДГ1 середній вік становив 51,9ะ9,5 року, у ДГ2 - 48,7 $\pm 13,4$ року. Контрольну групу (КГ) становили 49 хворих із XXН І-ІІ стадій, які аналогічно були розподілені на дві підгрупи: КГ1 - 26 хворих із діабетичною нефропатією (ДН), КГ2 - 23 хворих без ЦД відповідно. Середній вік хворих у контрольній групі становив 
49,3ะ17,1 року, причому в КГ1 середній вік становив $58,1 \pm 10,4$ року, а в КГ2-39,3 17,8 року відповідно.

Для визначення кардіоваскулярного ризику оцінювалися лабораторні показники. Проведено аналіз ліпідного профрілю (загальний холестерин (ХC), ліпопротеїди високої щільності (ЛПВЩ), ліпопротеїди низької щільності (ЛПНЩ), тригліцериди (ТГ), індекс атерогенності (IA)) та еритроцитів і гемоглобіну відповідно. За допомогою формули Фрідвальда вираховували ЛПНЩ: ХС - ЛПВЩ — 0,45хТГ. Індекс атерогенності вираховували за формулою: (ХС - ЛПНЩ)/ЛПВЩ. Статистичну обробку даних виконано програмою Microsoft Excel 2010. Вірогідність відмінностей між порівняльними групами визначали за допомогою параметричного критерію Стьюдента.

\section{Результати та їх обговорення}

XXH асоціюється 3 частим виникненням кардіоваскулярних патологій та часто супроводжується порушенням ліпідного обміну. Дисгіперліпідемії в пацієнтів із XXН трапляються частіше, ніж у загальній популяції. При цьому ступінь порушення ліпідного просрілю варіює від функції нирок, відповідно від швидкості клубочкової фрільтрації та вираженості протеїнурії. Результати нашого дослідження продемонстрували помітний атерогенний профіль як у дослідних групах, так і в контрольній групі із ЦД (табл. 1).

Як свідчать дані табл. 1, показники ліпідного профрілю в ДГ1 та ДГ2 не мали статистично значущої різниці ( $>0,05)$, але простежити безпосередній вплив ЦД на рівень ліпідного профрілю в дослідних групах майже неможливо, тому що сама уремія $€$ незалежним предиктором серцево-судинних патологій і також впливає на ліпідний профріль, що доведено багатьма дослідженнями. Відзначено також, що стать, вік і тривалість захворювання не є визначальними в розвитку будь-якого з типів дисліпідемії, хоча більш виражені зміни були виявлені в чоловіків, курців і пацієнтів, старших від 60 років. Слід, однак, відзначити, що зі збільшенням діалізного віку пацієнтів з'являлися більш серйозні порушення ліпідного профілю, включаючи всі ліпідні фрракції, що $є$ наслідком уремічної інтоксикації і наростання катаболічних процесів у цієї категорії хворих [8, 9].

Одним із доведених фракторів ризику кардіоваскулярної патології є вторинна анемія, яка виникає у хворих із XXН. Прогресування вторинної анемії прямо пропорційне до прогресування стадії XXН. Наявність у хворого XXН, анемії та хронічної серцевої недостатності (XCH) призводить до утворення так званого патологічного трикутника, який називають «кардіоренальний анемічний синдром». Наявність навіть легкого ступеня анемії у хворих із XXН призводить до підвищення ризику смерті пацієнтів, у яких в анамнезі $є$ XCH, стенокардія, гіпертросрія лівого шлуночка, перенесений інфраркт міокарда, інсульт, тромбоемболія легеневої артерії [10]. Середньоарифрметичні показники еритроцитів та гемоглобіну наведено в табл. 2.

Чітко простежується статистично значуща різниця між показниками аналізу крові в ДГ1 і КГ1, що підтверджує негативний вплив уремії на органи кровотворення та показники

\section{Таблиця 1}

Показники ліпідного профілю в дослідних та контрольних групах

\begin{tabular}{|c|c|c|c|c|}
\hline Показники & $\begin{array}{l}д \Gamma 1, \\
n=20(M \pm m)\end{array}$ & $\begin{array}{l}\text { дг2, } \\
n=24(M \pm m)\end{array}$ & $\begin{array}{l}K \Gamma 1 \\
n=26(M \pm m)\end{array}$ & $\begin{array}{l}K \Gamma 2, \\
n=23(M \pm m)\end{array}$ \\
\hline Холестерин & $6,7 \pm 1,8$ & $5,5 \pm 1,1$ & $7,4 \pm 1,6$ & $5,3 \pm 0,9$ \\
\hline ЛПВЩ & $1,0 \pm 0,2$ & $1,0 \pm 0,1$ & $1,1 \pm 0,2$ & $1,3 \pm 0,2$ \\
\hline ЛПНЩ & $4,6 \pm 1,8$ & $3,6 \pm 1,0$ & $5,2 \pm 1,6$ & $3,2 \pm 0,9$ \\
\hline ТГ & $2,5 \pm 0,6$ & $2,0 \pm 0,6$ & $2,5 \pm 0,6$ & $1,7 \pm 0,4$ \\
\hline IA & $2,2+0,5$ & $1,9 \pm 0,3$ & $2,0 \pm 0,3$ & $1,6 \pm 0,2$ \\
\hline
\end{tabular}

Примітка: p>0,05 — достовірність відмінностей між ДГ1 і ДГ2, а також КГ1 і КГ2.

\section{Таблиця 2}

Середньоарифметичні показники аналізу крові для визначення вторинної анемії в дослідних та контрольних групах

\begin{tabular}{lllll}
\hline Показники & $\begin{array}{l}\mathbf{L} \mathbf{1}, \\
\mathbf{( M \pm m )}\end{array}$ & $\begin{array}{l}\mathbf{L} \mathbf{2}, \\
\mathbf{( M} \pm \mathbf{m})\end{array}$ & $\begin{array}{l}\mathbf{K} \mathbf{1}, \\
\mathbf{( M \pm m}\end{array}$ & $\begin{array}{l}\mathbf{K} \mathbf{2}, \\
\mathbf{( M} \pm \mathbf{m})\end{array}$ \\
\hline Еритроцити & $2,9 \pm 0,3$ & $2,9 \pm 0,8$ & $4,0 \pm 0,7^{*}$ & $4,4 \pm 0,6^{* *}$ \\
Гемоглобін & $83,1 \pm 12,0$ & $84,5 \pm 14,3$ & $118 \pm 19,2^{*}$ & $133 \pm 17,3^{* *}$ \\
\hline
\end{tabular}

Примітка: * рівень значущості відмінностей $p<0,025, p \geq 0,05$ ДГ1 і КГ1, ** рівень значущості відмінностей $p<0,05, p<0,025$ ДГ2 і КГ2.

\section{Таблиця 3}

Фосфоро-кальцієві показники дослідних та контрольних груп

\begin{tabular}{|c|c|c|c|c|}
\hline Показники & $\begin{array}{l}\text { ДГ1, n (\%) } \\
(\mathrm{M} \pm \mathrm{m})\end{array}$ & $\begin{array}{l}\text { ДГ2, n (\%) } \\
(\mathrm{M} \pm \mathrm{m})\end{array}$ & $\begin{array}{l}\mathrm{K} \Gamma 1, \mathrm{n}(\%) \\
(\mathrm{M} \pm \mathrm{m})\end{array}$ & $\begin{array}{l}\mathrm{K} \Gamma 2, \mathrm{n}(\%) \\
(\mathrm{M} \pm \mathrm{m})\end{array}$ \\
\hline Гіпокальціємія & $12(60,0 \%)$ & $13(54,2 \%)$ & $2(7,7 \%)$ & $1(4,3 \%)$ \\
\hline Гіперфоссратемія & $17(85,0 \%)$ & $21(87,5 \%)$ & $4(15,3 \%)$ & $1(4,3 \%)$ \\
\hline Кальцій & $1,6 \pm 0,6$ & $1,7 \pm 0,5$ & $2,2 \pm 0,2$ & $2,3 \pm 0,2$ \\
\hline Фосфор & $2,0 \pm 0,5$ & $2,2 \pm 0,5$ & $1,3 \pm 0,1$ & $1,3 \pm 0,1$ \\
\hline
\end{tabular}

Примітка: p>0,05 — достовірність відмінностей між ДГ1 і ДГ2, а також КГ1 і КГ2. 
крові ( $p<0,025, p \geq 0,05)$. У ДГ2 і КГ2 також простежується чітко статистично значуща різниця $(p<0,05, p<0,025)$.

Однією із частих та тяжких проблем на нирково-замісній терапії є контроль фоссрор-кальцієвого обміну. Порушення мінерального обміну, стійка гіперфосфатемія та гіпокальціємія призводять до вторинного гіперпаратиреозу (ВГПТ). ВГПТ, що розвивається у хворих із ХХH, призводить не тільки до фіброзно-кістозної остеодистрофії, а й до кальцифрікації судин та клапанів серця, гіпертрофії лівого шлуночка, вторинної анемії (унаслідок остеосклерозу кісткового мозку). Зокрема, у ДГ1 у 12 (60,0\%) хворих відмічається зниження рівня кальцію від ресрерентних значень та в 17 (85,0\%) хворих підвищення рівня фосфрору. Така тенденція простежується і в ДГ2: зниження рівня кальцію - у 13 (54,2\%) хворих та гіперфоссратемії - у 21 (87,5\%) пацієнта (табл. 3).

Досліджуючи серцево-судинні ускладнення, які виникають у діалізних хворих із ЦД та без нього, виявлено, що зі збільшенням діалізного віку збільшується частота ССЗ. Супутній ЦД пришвидшує процес виникнення цих ускладнень (графрік 1 і 2).

\section{Графік 1}

Відносна частота виникнення серцево-судинних захворювань у діалізних хворих без цукрового діабету 2-го типу

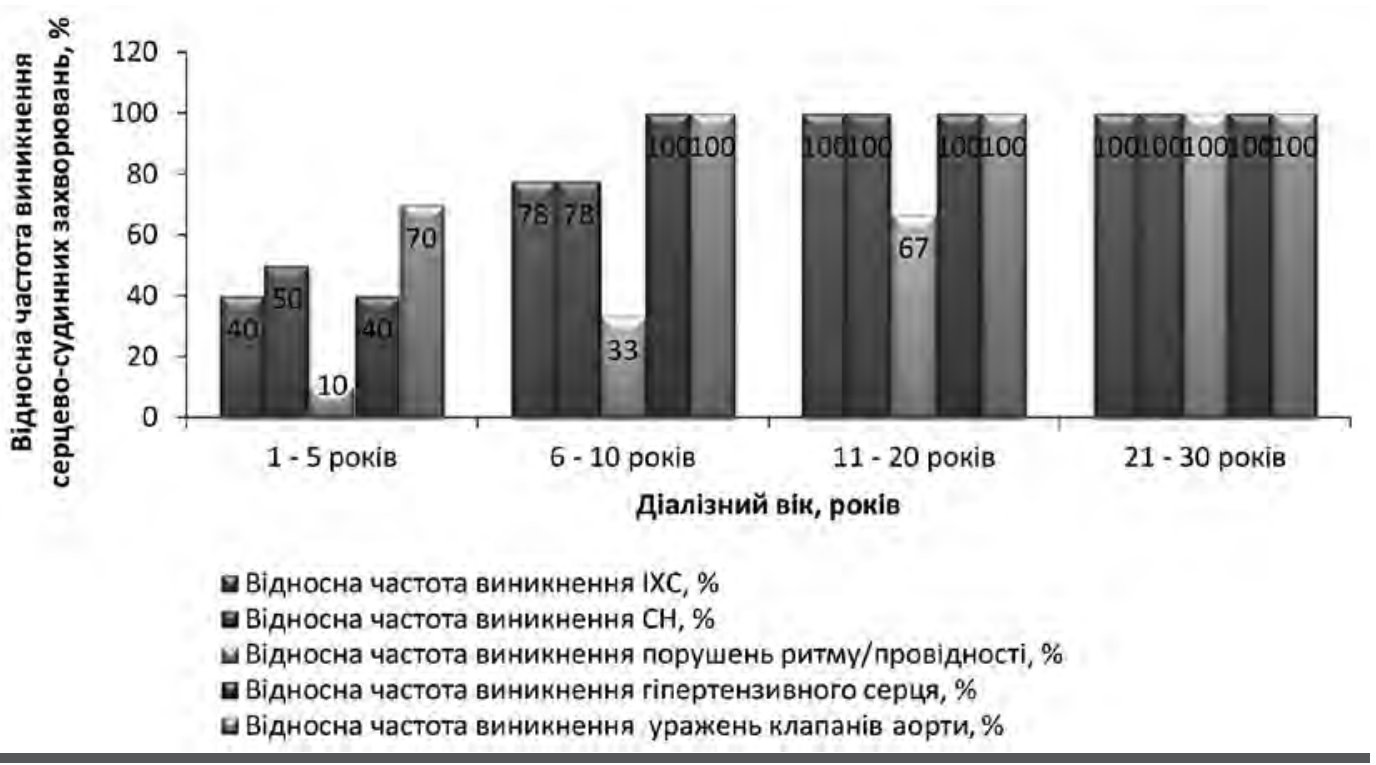

\section{Графік 2}

Відносна частота виникнення серцево-судинних захворювань у діалізних хворих із цукровим діабетом 2-го типу

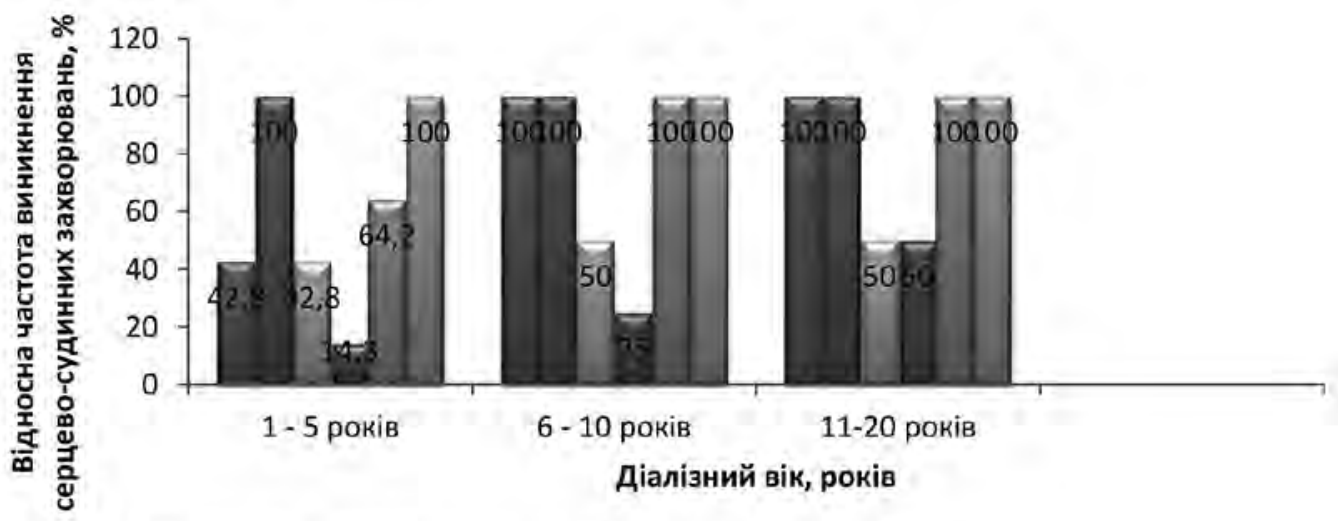

๒ Відносна частота виникнення IXC, \%

घ Відносна частота виникнення СН, \%

๘ Відносна частота виникнення порушень ритму/провідності, \%

в Відносна частота IM/ГПМК, \%

У Відносна частота виникнення гіпертензивного серця, \%

$\square$ Відносна частота виникнення уражень клапанів аорти, \% 


\section{Висновки}

Для профрілактики кардіоваскулярного ризику в пацієнтів, що перебувають на нирково-замісній терапії, необхідно проводити постійний моніторинг стану ліпідного профрілю, глюкози крові, рівня кальцію та фоссрору в сироватці крові, показників еритроцитів та гемоглобіну. При виникненні незначних змін цих показників необхідна своєчасна медикаментозна терапія для зниження ризику виникнення та прогресування СС3. Визнання XXН та ЦД 2-го типу незалежними факторами ризику розвитку ССЗ визначає тактику ведення хворих із ССЗ та XXН.

\section{Список використаної літератури}

1. Ефремова, ОА, Головин АИ, Ходыкина ЮЕ. Особенности фросфорно-кальциевого обмена у больных, находящихся на лечении программным гемодиализом. Научный результат. Сер. Медицина и фрармация. 2016;2(4):24-9. DOI: 10.18413/2313-8955-2016-24-24-29.

2. Lee WC, Lee YT, Li LC, Ng HY, Kuo WH, Lin PT et al. The Number of Comorbidities Predicts Renal Outcomes in Patients with Stage 3-5 Chronic Kidney Disease. J Clin Med. 2018 Dec;7(12):493. DOI:10.3390/jcm7120493.

3. Genovesi S, Boriani G, Covic A, Vernooij RWM, Combe C, Burlacu A et al. Sudden cardiac death in dialysis patients: different causes and management strategies. Nephrology Dialysis Transplantation. 2021;3(36):396-405.

4. Kramer A, Pippias M, Vianda S, Bonthuis M, Diez JMA, Afentakis N. et al. Renal replacement therapy in Europe: a summary of the 2013 ERA-EDTA registry annual report with a focus on diabetes mellitus. Clin. Kidney J. 2016;3(9):457-69. DOI: 10.1093/ckj/sfv151.

5. Gansevoort RT, Correa-Rotter R, Hemmelgarn BR, Jafar TH, Heerspink HJL, Mann JF et al. Chronic kidney disease and cardiovascular risk: epidemiology, mechanisms, and prevention. Lancet. 2013 Jul;382(9889):339-52. D0l:10.1016/S0140-6736(13)60595-4.

6. American Diabetes Association. Microvascular complications and footcare. Standards of medical care in diabetes - 2020. Diabetes Care.2020 Jan;1(43):135-151. DOI:10.2337/dc20-SO11.

7. Сердечно-сосудистый риск и хроническая болезнь почек: стратегии кардио-нефропротекции. Российский кардиологический журнал. 2014;8(112):7-37.

8. Bulbul MC, Dagel T, Afsar B, Ulusu NN, Kuwabara M, Covic A, et al. Disorders of Lipid Metabolism in Chronic Kidney Disease. Blood Purification. 2018;2(46):144-152. DOI: 10.1159/000488816.

9. Zhan X, Yang M, Chen $Y$, Zhang L, Yan C, Wang Y. Comparison of risk of stroke in patients treated with peritoneal dialysis and hemodialysis: a systematic review and meta-analysis. Ren Fail. 2019;1(41):650-656. D0I:10.1080/0886022X.2019.1632210

10. Steinvil M. Banai S, Leshem-Rubinow E. The development of anemia of inflammation during acute myocardial infarction. International J. Cardiol. 2012;2(156):160-4. DOI:10.1016/j.ijcard.2010.10.031. 